\title{
Genes within genes: independent expression of phage $T 4$ intron open reading frames and the genes in which they reside
}

\author{
Jonatha M. Gott, ${ }^{1,4}$ Ann Zeeh,, ${ }^{1}$ Deborah Bell-Pedersen,, ${ }^{1,2}$ Karen Ehrenman, ${ }^{2,3}$ Marlene Belfort, ${ }^{2}$ and \\ David A. Shub ${ }^{1}$ \\ ${ }^{1}$ Department of Biological Sciences, State University of New York at Albany, Albany, New York 12222 USA; ${ }^{2}$ Wadsworth \\ Center for Laboratories and Research, New York State Department of Health, Albany, New York 12201 USA; ${ }^{3}$ Department of \\ Microbiology and Immunology, Albany Medical College, Albany, New York 12208 USA
}

The $t d, n r d \mathrm{~B}$, and sunY introns of bacteriophage T4 each contain a long open reading frame (ORF). These ORFs are preceded by functional $T 4$ late promoters and, in the case of the nrdB intron ORF, a functional middle promoter. Expression of phage-encoded intron ORF-lacZ fusions indicates that these T4 genes are highly regulated. The lack of translation of these ORFs from the early pre-mRNAs can be accounted for by the presence of secondary structures that are absent from the late RNAs. Because translation of the intron ORFs could disrupt core structural elements required for pre-mRNA splicing, such regulation may be necessary to allow expression of the genes in which they reside.

[Key Words: Long open reading frames; T4 introns; splicing; translation]

Received July 15, 1988; revised version accepted October 19, 1988.

Group I and group II introns from a variety of sources contain long open reading frames (ORFs), which lie either entirely within the intron boundaries or occur in phase with the preceding exon. Intron ORFs in fungal mitochondria have thus far been shown to encode ribosomal proteins (Burke and RajBhandary 1982), as well as functions associated with splicing (maturases) (Lazowska et al. 1980; Schmelzer et al. 1981; De La Salle et al. 1982; Anziano et al. 1982; Weiss-Brummer et al. 1982; Carignani et al. 1983; Rochaix et al. 1985) and with the implied mobility of group I and group II introns (Jacquier and Dujon 1985; Macreadie et al. 1985; Michel and Lang 1985; Colleaux et al. 1986; Dujon et al. 1986; Lemieux and Lee 1987).

Therefore, it was of interest to find that each of the three group I introns in bacteriophage $\mathrm{T} 4$ contains a long ORF, each with a potential translational start within the intron (Chu et al. 1986; Sjöberg et al. 1986; Tomaschewski and Rüger 1987). These introns are located in the T4 genes $t d, n r d \mathrm{~B}$, and $\operatorname{sun} \mathrm{Y}$, which encode thymidylate synthase, the small subunit of ribonucleoside diphosphate reductase, and a $70-\mathrm{kD}$ protein of unknown function, respectively. Recent evidence suggests that the $t d$ and sunY ORFs promote the mobility of their respective introns (M. Belfort, S. Quirk, and D. Bell-Pedersen,

4Present address: Department of Chemistry and Biochemistry, University of Colorado, Boulder, Colorado 80309 USA. unpubl.|, similar to the omega protein encoded within the intron of the large rRNA gene of yeast mitochondria (Jacquier and Dujon 1985; Macreadie et al. 1985).

The three T4 intron ORFs are organized in an unusual manner. Although they start in a region looped out of the conserved core structure, their 3' ends overlap structural elements believed to be important in the excision of these introns. This arrangement prompted us to suggest a negative regulatory coupling of splicing and translation in this and other systems (Shub et al. 1987, 1988). As a first step in testing this model, it was necessary to demonstrate that these intron ORFs are actually translated in vivo and to identify the transcripts from which they are expressed.

During the course of phage infection, a complex series of modifications and additions to the host RNA polymerase results in the synthesis of transcripts from early, middle, and late T4 promoters. Factors involved include the motA gene product, which is required for transcriptional activation of T4 middle promoters (Mattson et al. 1977; Brody et al. 1983; Guild et al. 1988), and the product of gene 55, which encodes the RNA polymerase $\sigma$-subunit required for initiation of transcription from T4 late promoters (Kassavetis and Geiduschek 1984).

We show here that the products of the T4 intron ORFs are synthesized during the course of T4 infection and therefore represent true genes within genes. Moreover, these ORFs are expressed from their own promoters, independently of the genes in which they reside. 


\section{Results}

\section{RNAs derived from the T4 td gene}

To determine the kinetics of expression of RNAs derived from the T4 $t d$ gene, RNA was isolated from Escherichia coli B at 3, 6, 9, and 12 min after infection by wild-type T4B phage. An end-labeled oligodeoxynucleotide complementary to sequences in the second exon was annealed to these RNA preparations and extended using reverse transcriptase. At the earliest time after infection ( $3 \mathrm{~min})$, the cDNA of $1.65 \mathrm{~kb}$, corresponding to the pre-mRNA, was the major species present (Fig. 1A). At 6 min postinfection an additional species of $0.65 \mathrm{~kb}$ became apparent (Fig. 1A). This cDNA was the size ex-

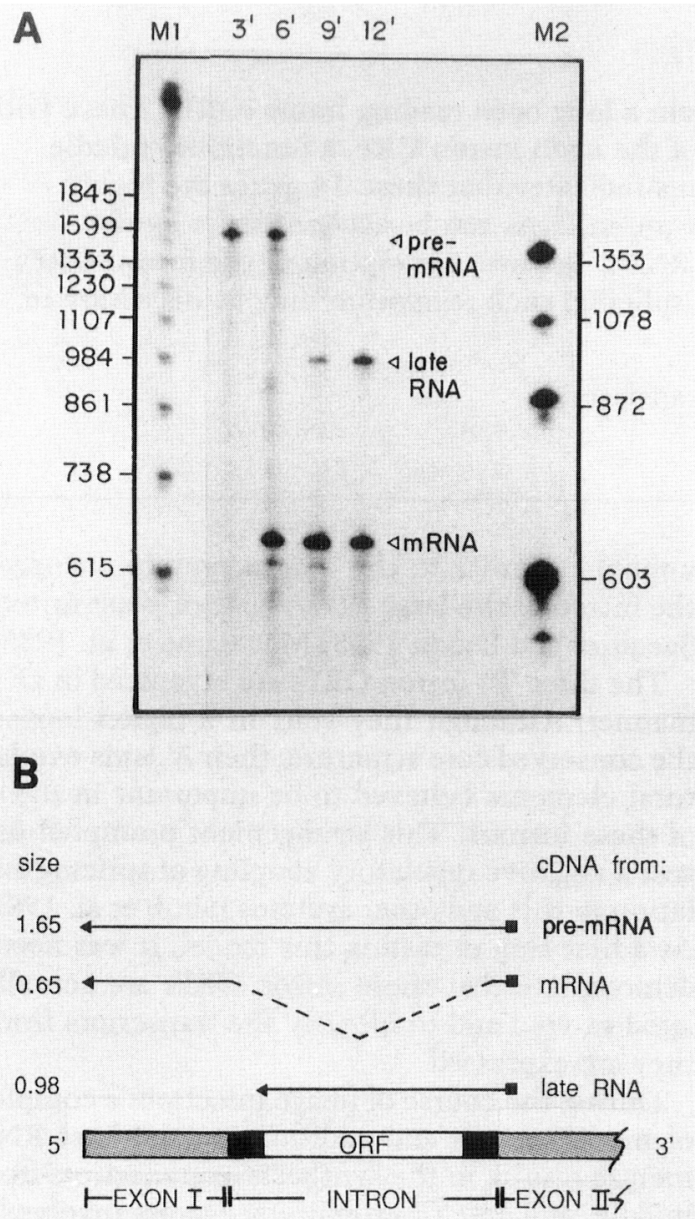

pected for the spliced mRNA (pre-mRNA with the 1016nucleotide $t d$ intron removed). A third species of $0.98 \mathrm{~kb}$ began to appear at $9 \mathrm{~min}$, becoming more prominent by 12 min (Fig. 1A). Interestingly, the $5^{\prime}$ end of the corresponding RNA fell in the region around the start of the intron ORF (Fig. 1B). Extension of an intron-specific primer in the presence (Fig. 2, lanes 1-4) or absence (Fig. 2 , lane 5) of dideoxynucleotides mapped the 5 ' end of this delayed RNA to a $\mathrm{C}$ residue, 20 nucleotides upstream of the first AUG of the $t d$ intron ORF.

The time course of appearance of this RNA species (Fig. 1C) suggested that it might have arisen from a T4 late promoter. To test this possibility, the primer extension experiments were repeated using RNA from cells infected with phage containing an amber mutation in gene 55. RNA was isolated from $\mathrm{Su}^{+}$or $\mathrm{Su}^{-}$cells at middle $(7 \mathrm{~min}$ ) or late $(19 \mathrm{~min})$ times after infection by either wild-type or T4 $55_{\mathrm{am}}$ phage. As predicted, when wild-type T4 RNA $\left(55^{+}\right)$from either host was used as template, the pertinent cDNA band was present at late (Fig. 2, lanes 9 and 13), but not earlier (Fig. 2, lanes 8 and 12), times after infection. Similar results were seen with RNA isolated from T4 $55_{\mathrm{am}}$ phage grown in an ambersuppressing host (Fig. 2, lanes 6 and 7). In contrast, the late RNA species was not present at either time after infection of a Su- host by $\mathrm{T} 455_{\text {am }}$ phage (Fig. 2, lanes 10 and 11), suggesting that the T4 gene 55 product is required for production of this RNA.

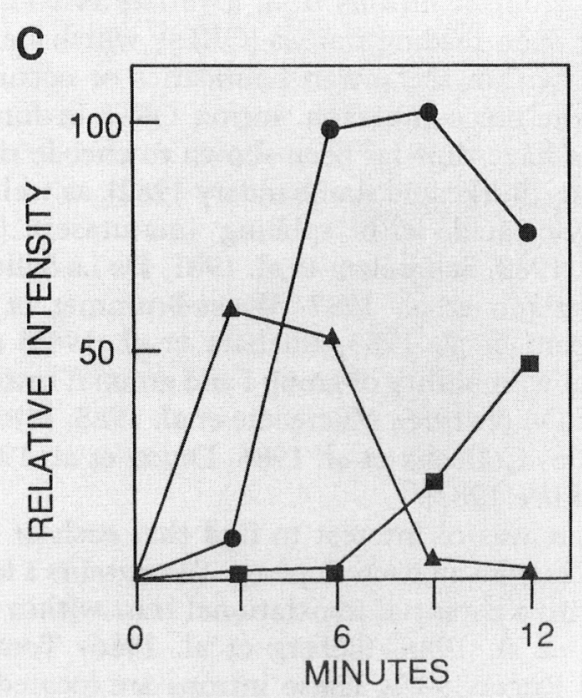

Figure 1. RNAs expressed from the T4 $t d$ gene. $(A)$ Primer extension analyses. ${ }^{32}$ P-End-labeled $t d$ exon II-specific oligodeoxynucleotide was hybridized to RNAs isolated 3, 6, 9, or 12 min after infection of $E$. coli B by wild-type T4 phage and extended, using reverse transcriptase. Products were separated on a 5\% polyacrylamide/8 $\mathrm{M}$ urea gel and subjected to autoradiography. ${ }^{32} \mathrm{P}$-End-labeled $123-\mathrm{bp}$ DNA ladder (Bethesda Research Laboratories) (M1), and $\phi$ X174-HaelII fragments (M2) were denatured and run as size standards. cDNAs attributable to the precursor RNA (pre-mRNA), spliced mRNA, and late RNA species present in the RNA samples are indicated. $(B)$ Schematic representation of RNA species arising from the $t d$ gene. Small, filled boxes represent the oligodeoxynucleotide used as the primer in the experiment in $A$. The cDNA products are shown relative to the intron (filled ends represent the phylogenetically conserved core structural regions involved in intron excision) and exons of the $t d$ gene. Sizes of each of these species in $\mathrm{kb}$ are as marked. $(C)$ Time course of expression of $t d$ RNAs. Relative intensity of the cDNA signal, derived from densitometric tracings of the autoradiogram shown in $A$, is plotted versus time after T4 infection. (A) Precursor RNA; $(\bullet)$ spliced RNA; ( $)$ late RNA. 


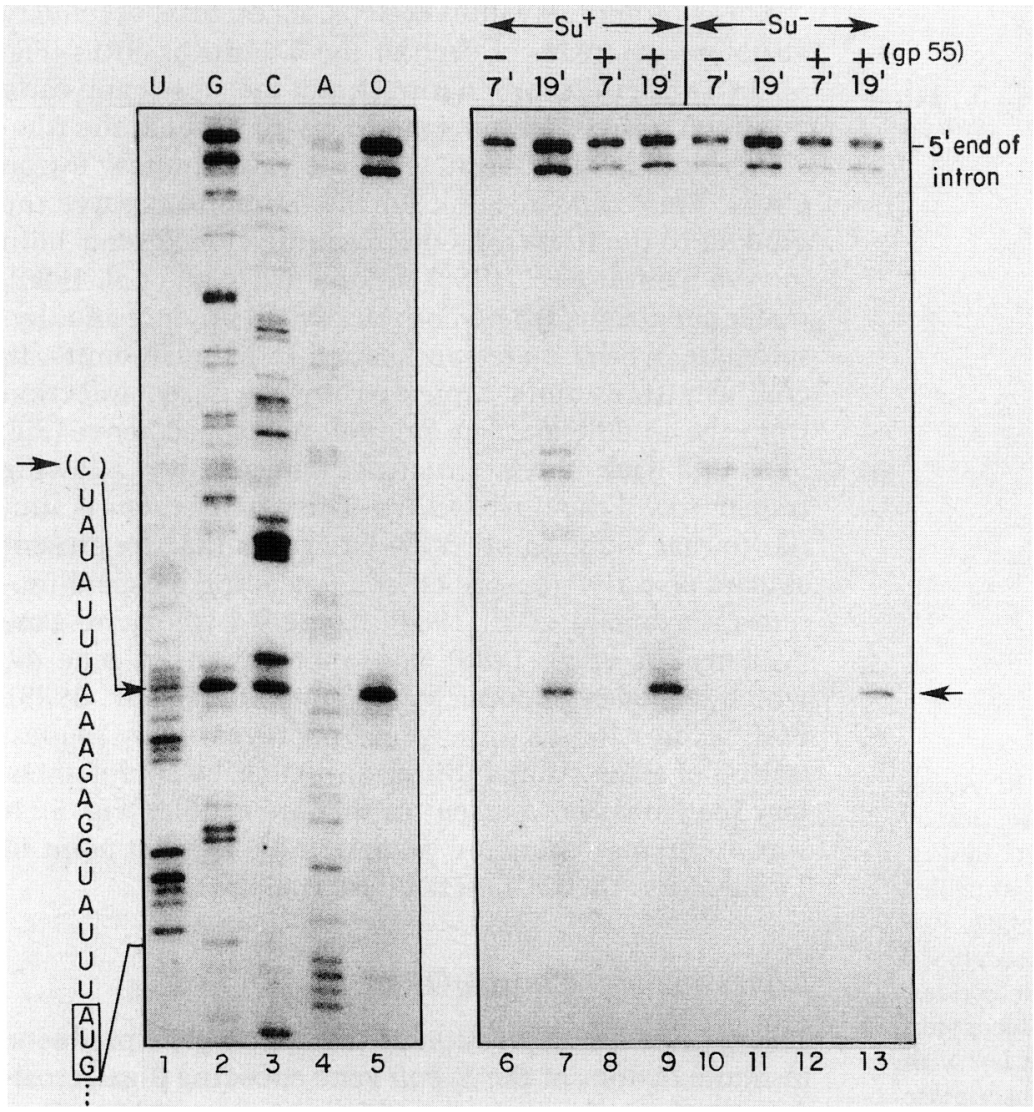

Figure 2. Mapping the $5^{\prime}$ end of the $t d$ late RNA. RNA was extracted from E. coli NM275 (Su ${ }^{-}$; Belfort et al. 1985) or $\mathrm{C} 600$ $\left\langle\mathrm{Su}^{+}\right\}$at 7 or $19 \mathrm{~min}$ after infection by wildtype [gp $55^{+},(+)$or amBL292 [gp 55-, $(-1]$ phage, as indicated above lanes $6-13$. End-labeled intron-specific primer was annealed to each RNA and extended, using reverse transcriptase. The RNA sequencing reactions in lanes 1-5 used RNA from $\mathrm{Su}^{+}$cells, 19 min after infection by wild-type $\mathrm{T} 4$, and were carried out in the absence (lane 5) or presence of one of the dideoxynucleotides (the complement of the nucleotide given above lanes 1-4). The RNA sequence is given at left, with the initiation codon of the ORF boxed. Arrows indicate the position of a strong reverse transcriptase stop present under conditions where active gene 55 product is made (lanes 5, 7, 9, and 13), representing the start of the late transcript.

The simplest interpretation of these data, namely that this ORF-encoding RNA arises from gene-55-dependent transcriptional initiation, is supported by the presence in this region of a sequence homologous to a T4 late promoter (Table 1). Furthermore, we have ruled out the possibility of this late RNA being a splice product, as it appears with identical kinetics in $\mathrm{T} 4 t d$ splicing-defective mutants (data not shown).

\section{$R N A$ products of the $\operatorname{nrd} B$ and $\operatorname{sun} Y$ introns}

The presence of a potential late gene within the $t d$ intron prompted us to examine the sequences upstream of the other T4 intron ORFs. The $n r d \mathrm{~B}$ intron ORF is preceded by consensus middle and late promoters, whereas a consensus late promoter is present $18 \mathrm{bp}$ upstream of the sunY intron ORF (Table 1). To test whether these potential promoters are actually used by T4, end-labeled oligomers complementary to sequences within the ORFs were annealed to total RNA from cells $\left(\mathrm{Su}^{-}\right)$infected by wild-type T4, T4 mot $\mathrm{A}_{\mathrm{am}}$ (Mattson et al. 1977; Shinedling et al. 1987), or T4 $55_{\mathrm{am}}$ phage and extended with reverse transcriptase.

When an $n r d B$ intron oligomer is used to prime reverse transcription of wild-type RNA, strong stops are seen at the putative middle and late promoters at $7 \mathrm{~min}$ and $19 \mathrm{~min}$ after infection, respectively (Fig. 3, lanes 5 and 10). A similar pattern is seen when RNA from T4 $m_{0} A_{a_{m}}$-infected cells is used (Fig. 3, lanes 7 and 8), ex- cept that RNA arising from the putative middle promoter is reduced at $7 \mathrm{~min}$. Some transcription from this promoter is expected in $\mathrm{T} 4 \operatorname{mot} \mathrm{A}_{\mathrm{am}}$ phage, given the similarities of the -10 region of middle promoters to

Table 1. Potential promoter sequences upstream of the T4 intron ORFs

\begin{tabular}{|c|c|c|}
\hline \multicolumn{3}{|c|}{ Matches to consensus promoter sequences ${ }^{a}$} \\
\hline & -30 & -10 \\
\hline $\begin{array}{l}\text { T4 middle } \\
\text { promoter }^{b}\end{array}$ & ${ }_{T}^{A} \underset{T}{A} T G C T T_{C}^{T} A . . N_{11-13}$ & . . TAnnnT \\
\hline$n r d \mathrm{~B}$ intron ORF & TTTGCTTGC . . . $\mathrm{N}_{12} \ldots$ & $\cdots$ TATAAT \\
\hline T4 late promoter & TATAAATAnn a y $\mathrm{R}_{\mathrm{T}}^{\mathrm{A}}$ & \\
\hline$t d$ intron ORF & AATAAATACTTCTATA & \\
\hline$n r d B$ intron ORF & $\underbrace{\text { TATAAATATGATTATA }}_{*}$ & \\
\hline sun $\mathrm{Y}$ intron $\mathrm{ORF}$ & TATAAATATGAATACG & \\
\hline
\end{tabular}

a Bases matching the consensus are underlined.

b -30 and -10 refer to positions relative to the transcriptional start site (from Guild et al. 1988).

c Bases indicated by uppercase letters represent nucleotides present in all $14 \mathrm{~T} 4$ late promoters used to determine this consensus (Kassavetis et al. 1986). Weaker homology $(>10 / 14)$ is indicated by lowercase letters. Transcriptional start sites are denoted with asterisks $\left({ }^{*}\right)$. (y) Pyrimidine; (r) purine; (n) any nucleotide. 


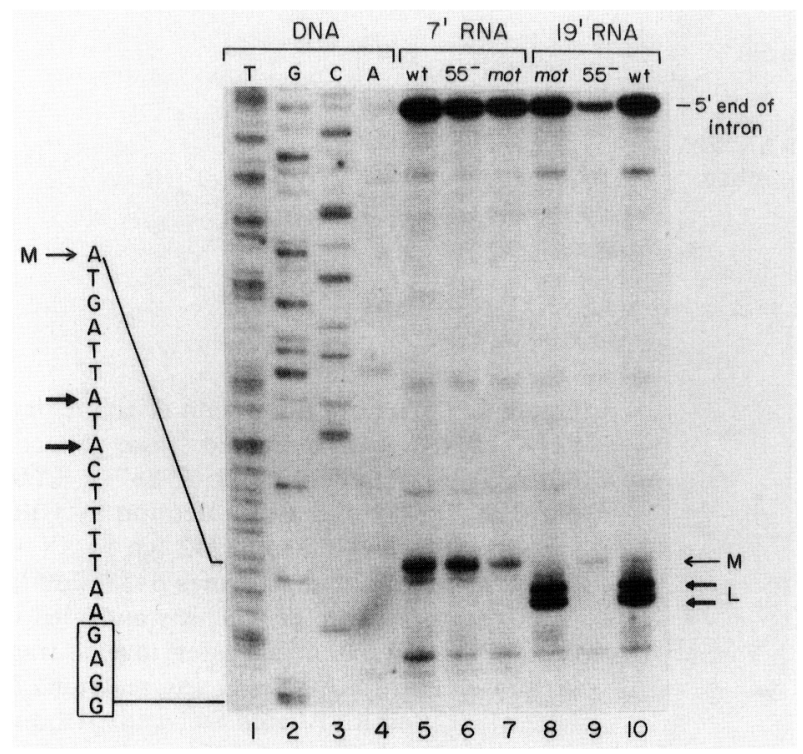

Figure 3. Primer extension analyses of $n r d \mathrm{~B}$ RNAs. RNA was extracted from $E$. coli $\mathrm{B}_{\mathrm{E}}\left(\mathrm{Su}^{-}\right)$at 7 or $19 \mathrm{~min}$ after infection by wild-type (wt), amBL292 (55-), or amG1 (mot) phage. End-labeled $n r d \mathrm{~B}$ intron-specific oligodeoxynucleotide was annealed with each RNA and extended, using reverse transcriptase. Parallel reactions were carried out, using single-stranded pJSS10 DNA (see Experimental procedures) and dideoxynucleotides. (Lanes 1-4) Labeled with the complement of the dideoxynucleotide used in the reaction. The DNA sequence is at left with the putative S/D sequence boxed. Strong reverse transcriptase stops corresponding to middle (M) and late (L) T4 promoters are indicated with light and heavy arrows, respectively.

those utilized early in T4 infection (Brody et al. 1983; Guild et al. 1988). In contrast, while the middle promoter still is used efficiently by T4 $55_{\mathrm{am}}$ phage (Fig. 3 , lane 6), no RNA species arising from the T4 late promoter is detected (Fig. 3, lane 9). These data indicate that the $n r d \mathrm{~B}$ intron ORF is present as part of at least four separate RNA species during T4 infection: the early unspliced nrdB pre-mRNA, the excised intron, and middle and late mRNAs originating from separate promoters immediately upstream of its translational start.

These same RNA preparations were also used as templates for primer extension with an oligomer complementary to intron sequences of the sunY gene. The 7min RNA preparations from all phage yielded a number of discrete bands (Fig. 4, lanes 8-10). Like the common bands seen in Figure 3, these may have arisen from potential early promoters or specific processing events at these sites. Our data cannot distinguish between these and other possibilities. As expected, an RNA extending from the putative late promoter was the major species present in 19 min RNA isolated after infection by either wild-type T4 or T4 motA $\mathrm{am}_{\mathrm{am}}$ phage (Fig. 4, lanes 5 and 7). This species was reduced greatly when RNA from $T 4$ $55_{\mathrm{am}}$ phage was used as template (Fig. 4, lane 6). Thus, it appears that the late promoter sequence upstream of each of the T4 intron ORFs is utilized during T4 infection.
These promoters fall in regions of potential secondary structure upstream of each of the T4 intron ORFs (Fig. 5). In transcripts originating from the upstream early promoters, these hairpins are likely to occlude the ribosome binding sites of at least the $t d$ and $\operatorname{sunY}$ intron ORFs. This could account for the failure to observe the product of the $t d$ intron ORF from the cloned gene, both in vivo (Belfort et al. 1986) and in vitro (Chu et al. 1985), under conditions where both the exon I product and thymidylate synthase are synthesized in large amounts. In contrast, transcripts expressed during phage infection from the middle and late promoters mapped above (Fig. 5) would lack these structures, presumably allowing translation of the intron ORFs. This arrangement is similar to that found in other T4 late genes that are present as part of early transcripts: soc, encoding a capsid protein (Macdonald et al. 1984), $e$, the T4 lysozyme gene (McPheeters et al. 1986), and, more recently, gene 49, which encodes endonuclease VII (Barth et al. 1988). Early expression of these genes is prevented by sequestration of translational initiation signals by complementary sequences not present in the late mRNA (Fig. 5). It was of interest, therefore, to determine at what point in $\mathrm{T} 4$ infection the intron ORFs are translated.

\section{Expression of the intron ORFs}

To examine the expression of the intron gene products, in-frame fusions of the $E$. coli gene encoding $\beta$-galactosidase were made with each of the intron ORFs. Constructs pDZX1, pJZE1, and pAZP1 are fusions of $l a c Z$ to the $t d, n r d \mathrm{~B}$, and $\operatorname{sun} \mathrm{Y}$ ORFs, respectively (see Experi-

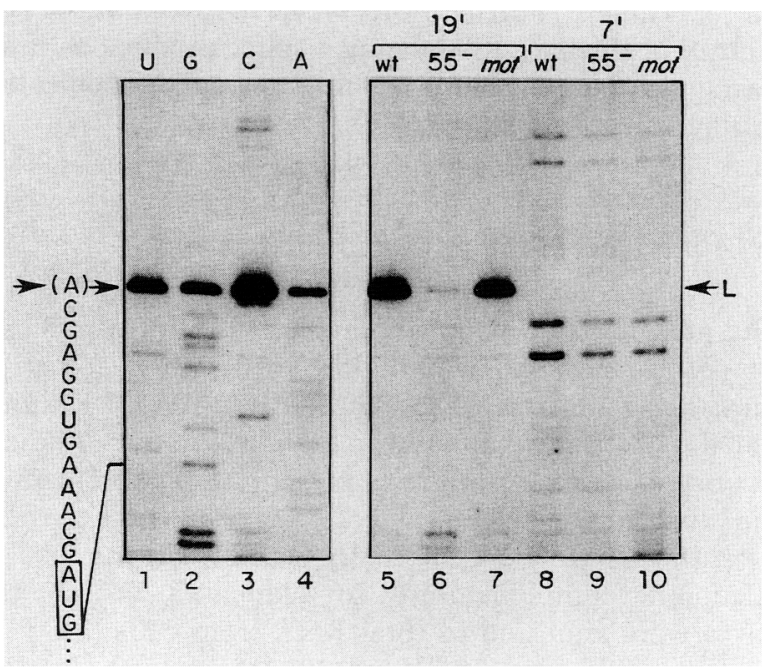

Figure 4. Primer extension analyses of sunY RNAs. A sunY intron-specific oligodeoxynucleotide was used to prime cDNA synthesis from equal amounts of the RNA preparations described in the legend to Fig. 3. Sequencing reactions (lanes 1-4) utilized 19 min RNA from wild-type-infected cells as template. Labels are as in Fig. 3 . The arrows indicate the start of the late transcript, with residues shown at the left. The initiation codon of the ORF is boxed. 

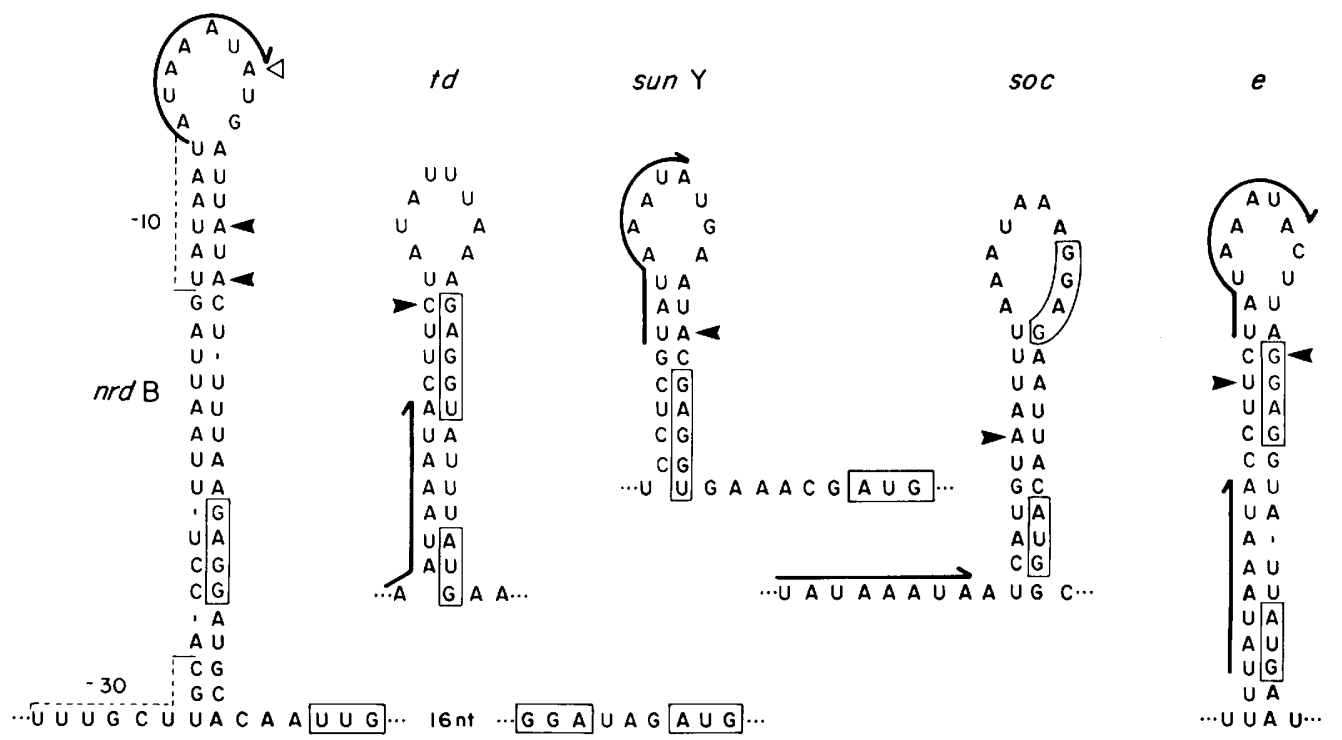

Figure 5. Transcriptional start sites and potential secondary structures upstream of the $\mathrm{T} 4 \mathrm{nr} d \mathrm{~B}$ intron ORF, $t d$ intron ORF, sunY intron ORF, soc, and $e$. Secondary structures and transcriptional start sites for soc and $e$ are taken from Macdonald et al. (1984) and McPheeters et al. (1986), respectively. Matches to consensus T4 middle (dashed lines) and the most highly conserved portion of T4 late (heavy arrows) promoters are indicated. Sites of initiation of middle $(\triangle)$ and late (filled arrowheads) transcripts are shown. Potential S/D sequences and initiation codons are boxed.

mental procedures). For comparative purposes, lac Z fusions were also made with exon I sequences from the $\operatorname{nrdB}(\mathrm{p} / \mathrm{ZB} 1)$ and $\operatorname{sun} \mathrm{Y}(\mathrm{pAZH} 1)$ genes.

To study their in vivo expression, each of these constructs was transferred into the phage genome via recombination between infecting phage DNA and homologous plasmid sequences flanking the fusions (Singer et al. 1981; Casna and Shub 1982). Cells containing the fusion plasmids were infected with $s a \Delta 9$, a phage containing a deletion of $2400 \mathrm{bp}$ in the region between $r \mathrm{IIB}$ and gene 52 (Depew et al. 1975). Use of a sizable deletion ensured that the T4 genome would be able to accommodate a 3-kb insert while still maintaining sufficient terminal redundancy for phage viability (Shub and Casna 1985). Progeny phage containing the lacZ fusions were identified by plaque hybridization and/or the formation of blue plaques on a lawn of lac deletion cells on X-Gal plates. Characteristic plaque phenotypes $\mid t d$ constructions), Southern blots ( $n r d \mathrm{~B}$ constructions), and protein labeling of phage-infected cells $(n r d \mathrm{~B}$ and $\operatorname{sun} \mathrm{Y}$ constructions) were used to confirm the correct localization of the fusion genes within the phage genome (data not shown).

Enzyme assays were used to quantitate the levels of $\beta$-galactosidase activity at various times after infection with each of the lacZ fusion phage (Fig. 6). A parallel infection with $s a \Delta 9$ rIIB (SSZ1), which contains an $r \mathrm{IIB}-1 a c \mathrm{Z}$ fusion expressed early in infection, was used as an internal standard in each experiment.

In vivo expression of thymidylate synthase, the product of the phage $t d$ gene, has been well characterized. Beginning by $3-5 \mathrm{~min}$ postinfection (Trimble et al. 1972; Belfort et al. 1985), enzyme production parallels the synthesis of the phage-encoded rIIB-lac Z fusion pro- tein (Fig. 6A) and correlates well with the appearance of the mature $t d$ mRNA (Fig. 1C; Belfort et al. 1985). However, initiation of synthesis of the $t d$ intron ORF-lacZ fusion extrapolates to $\sim 12 \mathrm{~min}$ after phage infection (Fig. 6A). This expression correlates with synthesis of the delayed RNA rather than the pre-mRNA, which also contains the ORF coding sequence. An amber mutation in gene 55 eliminates $\beta$-galactosidase activity in this construct in $\mathrm{Su}^{-}$cells, but not in $\mathrm{Su}^{+}$cells (Fig. 6A), indicating that this intron ORF is a true late gene.

Differential expression of the exon I and intron ORFs is also seen in the $\mathrm{T} 4 \mathrm{nrdB}$ (Fig. $6 \mathrm{~B}$ ) and $\operatorname{sunY}$ (Fig. $6 \mathrm{C}$ ) genes. The exon I-lacZ fusions are expressed early after infection, with a time course similar to the rIIB-lacZ fusion (not shown) in each experiment. Expression from the $n r d \mathrm{~B}$ intron ORF-lacZ fusion lagged behind that of the exon I fusion, with a dramatic increase in production of the intron ORF fusion protein extrapolating to $\sim 8$ min (Fig. 6B). These data are consistent with expression of the $\operatorname{nrdB}$ intron ORF from both the middle and late mRNAs but not the early pre-mRNA. However, preliminary experiments suggest that introduction of the $55_{\mathrm{am}}$ mutation does not appreciably alter the time course of synthesis of this fusion (data not shown). Synthesis of the sunY intron ORF fusion is not detected before 10 min after infection and is completely dependent upon the phage gene 55 (Fig. $6 \mathrm{C}$ ). Thus, like the ORF within the $t d$ intron, the sunY intron ORF encodes a late T4 protein.

\section{Discussion}

The data presented here demonstrate that the $\mathrm{T} 4$ intron ORFs are functional genes expressed from their own pro- 
Gott et al.
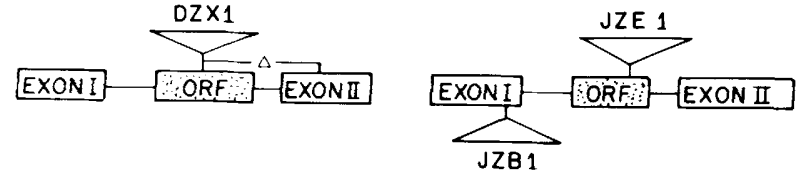

td

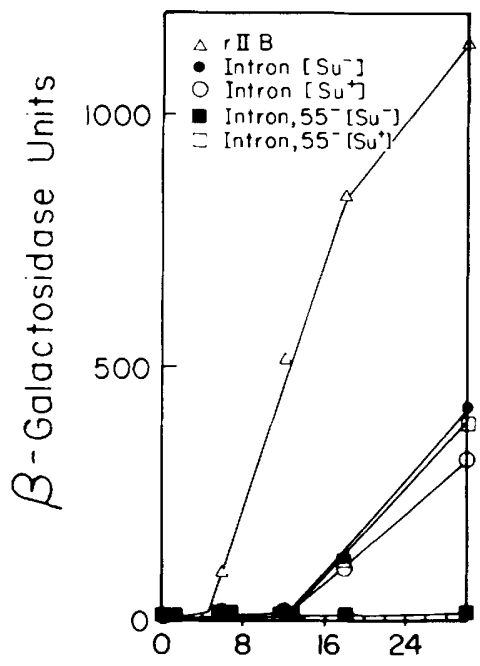

$\operatorname{nrd} \mathrm{B}$

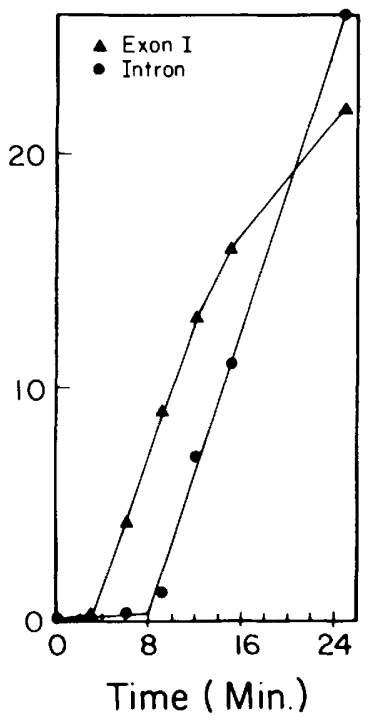

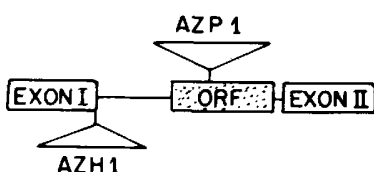

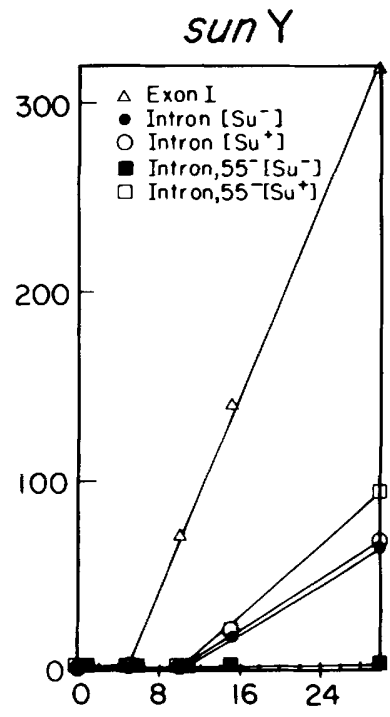

Figure 6. Expression of the lacZ fusions proteins. Schematic representation of the exon-lacZ and intron ORF-lacZ fusions present in the phage described in the text is shown at the top. Boxes represent coding sequences, with intron sequences outside of the ORFs indicated by lines. The intron ORFs are stippled, and the exons (I and II) are shown as open boxes. Sites of in-frame fusions with $E$. coli $l a c Z$ are indicated (not to scale). Intron and exon sequences deleted in the construction of the $t d$ ORF fusion (DZX) are shown. Phage containing the various intron ORF-lacZ and exon-lacZ fusions were used to infect E. coli $\mathrm{B}_{\mathbf{E}}\left(\mathrm{Su}^{-}\right)$or $\mathrm{B}_{40}\left(\mathrm{Su}^{+}\right)$, and cells were assayed for $\beta$-galactosidase activity at various times after infection. An $r \mathrm{IIB}-l a c Z$ fusion was used as a standard in each experiment (shown for $t d$ only). Note the different scales on the ordinates.

moters independently of the genes in which they reside. Although also present as part of early, intron-containing transcripts, these genes are not expressed until later in phage infection. This is consistent with our prediction that efficient splicing should be incompatible with translation of the ORFs (Shub et al. 1987, 1988). In the case of the $t d$ and sunY intron ORFs, this inhibition of translation is most likely due to the occlusion of their Shine-Dalgarno (S/D) sequences by stable secondary structures in the early mRNAs. Such structures are involved in the regulation of at least three other T4 late genes: $e$, soc, and 49.

The data indicate that regulation of the nrdB ORF may also occur at other levels. Like the $t d$ and sunY ORFs, the $n r d \mathrm{~B}$ intron ORF is not expressed early in infection, despite its presence as part of the pre-mRNA. The reasons for the delay are not as clear cut as for the $t d$ and sunY ORFs, however. The lack of early translation of the $n r d \mathrm{~B}$ intron ORF could be accounted for if that gene is initiated at the UUG $3^{\prime}$ of the proposed hairpin, which is preceded by a potential S/D sequence 8 nucleotides upstream (Fig. 5). In this secondary structure, the first AUG of the ORF would be free for translation, although the length ( 3 nucleotides) and spacing of the potential S/D sequence upstream of this AUG suggest that it would be used inefficiently (Stormo et al. 1982). Al- though not common, UUG is used as an initiation codon in some E. coli genes (Gren 1984). Independent evidence suggests that this UUG is used as a ribosome initiation site (D. McPheeters and L. Gold, pers. comm.), although expression of the intron ORF from this codon would also require a frameshift in this region. The low level of expression of the $n r d \mathrm{~B}-1 a c \mathrm{Z}$ fusion may reflect this additional level of regulation. Currently, we are investigating this possibility, as well as the use of other AUGs in the ORF.

The products of the T4 intron ORFs are nonessential, as demonstrated by the viability of phage containing intron ORF-lacZ fusions. This is not surprising, given the variable occurrence of these introns among the $T$-even phage (Pedersen-Lane and Belfort 1987; Quirk et al. 1988) and the viability of T4 phage containing exact deletions of one or more of these introns (D. Bell-Pederson, M.Q. Xu, and J. Gott, unpubl.). Indeed, given the function of the $t d$ and sunY intron ORF products in promoting intron mobility, the introns and their ORFs may simply represent molecular parasites, conferring no selective advantage to the phage. However, because the occurrence of separate, regulated promoters upstream of intron ORFs is unique to T4, this complex gene arrangement may play a functional role in the phage. This could involve either regulation of the $t d, n r d \mathrm{~B}$, and $\operatorname{sun} \mathrm{Y}$ genes 
or diminution of possible deleterious effects of the ORFencoded gene products.

A striking property of the three introns is that although the core elements involved in splicing are extremely similar in each, their ORFs bear no relationship to each other at the primary sequence level. Thus, although the core structures undoubtedly have a common ancestry, the ORFs seem to have arisen independently. Similar conclusions have been drawn for a Neurospora mitochondrial intron, which contains different ORFs in two closely related species (Mota and Collins 1988). The resemblance of the T4 introns and their ORFs to those found in other systems leads to interesting questions regarding both the origin of these introns and the mechanism by which these introns become established in such diverse biological niches.

\section{Experimental procedures}

\section{RNA extraction}

Cells were grown at $30^{\circ} \mathrm{C}$ in TBYE $\{1.0 \%$ Bacto-tryptone, $0.5 \%$ $\mathrm{NaCl}$, and $0.5 \%$ yeast extract) or in $\mathrm{M} 9 \mathrm{~S}$ plus $0.4 \%$ glucose [a minimal medium supplemented with amino acids (Bolle et al. 1968\| to an $\mathrm{Abs}_{650}$ of $0.2-0.3$. Media were supplemented with $50-100 \mu \mathrm{g} / \mathrm{ml}$ ampicillin for plasmid-carrying strains. T4 infections were at a moi of $\sim 7$. Cells were chilled rapidly, pelleted, and washed twice in $10 \mathrm{mM}$ Tris- $\mathrm{HCl}(\mathrm{pH} 7.5)$ and 100 $\mu \mathrm{g} / \mathrm{ml}$ chloramphenicol. RNA was extracted from cell pellets lysed by the lysozyme freeze-thaw method (Gott et al. 1986).

\section{End labeling of oligodeoxynucleotides}

Twelve pmoles of oligodeoxynucleotide were incubated for 45 min at $37^{\circ} \mathrm{C}$ in $100 \mathrm{~mm}$ Tris- $\mathrm{HCl}(\mathrm{pH} 8), 5 \mathrm{~mm}$ DTT, $10 \mathrm{~mm}$ $\mathrm{MgCl}_{2}$, and $0.2 \mathrm{mM}$ spermidine, in the presence of $50 \mu \mathrm{Ci}$ $\left[\alpha^{-32} \mathrm{P}\right] \mathrm{ATP}(3000 \mathrm{Ci} / \mathrm{mmole})$ and 1 unit T4 polynucleotide kinase. Samples were heated to $95^{\circ} \mathrm{C}$ for 3 min and quick-cooled on ice. End-labeled oligomers were either passed over Elutip-d columns (Schleicher \& Schuell) to reduce unincorporated label (for DNA sequencing and as hybridization probes) or deproteinized and ether extracted (for RNA sequencing).

\section{Primer extension and cDNA dideoxy sequence analysis}

Deproteinized RNA from T4-infected cells or single-stranded plasmid DNA was used as template for reverse transcription. Synthesis of cDNA in the presence of ddNTPs was according to Ehrenman et al. (1986). For determination of the $5^{\prime}$ ends of intron-specific RNAs, dideoxynucleotides were omitted from the RNA reactions. The primers used in these experiments included $t d$ exon II 5'-CCCCTGGAATAAGATTACAC-3' (coordinates 1839-1858 of Chu et al. 1984); $t d$ intron 5'-CTTTAGCACTTCCTACATATAC-3' (coordinates 946-967 of Chu et al. 1986); nrdB intron 5'-GTCCCGTTCTTAACCATTTC-3' (coordinates 1439-1458 of Sjöberg et al. 1986); and sunY intron 5'-GACTTATCAGGAAATCTTACC-3' (coordinates 3067-3087 of Tomaschewski and Rüger 1987).

\section{Construction of lac $Z$ fusion plasmids}

pDZXI contains an in-frame lacZ fusion to the $t d$ intron ORF at the unique $X b a \mathrm{I}$ site engineered into plasmid pUCTd $\Delta$ 1-3 (Belfort et al. 1987). The fusion was created by ligating the $X b a I-E c o R V$-digested $t d$ plasmid to XbaI-DraI-cleaved pFR97, which contains the $l a c Z$ sequences in the appropriate frame relative to the $X b a I$ site (Shapira et al. 1983). Those transformants in lac deletion strain M182 that gave positive hybridization signals with both lacZ and $t d$ (exon I) oligodeoxynucleotide hybridization probes were checked by restriction analysis for the appropriate fusion joint and for blue colony color on plates containing X-Gal and IPTG.

pJSS10, a plasmid containing the entire $n r d \mathrm{~B}$ gene, was used to generate the $n r d \mathrm{~B}-1 a c \mathrm{Z}$ fusions. To create pJSS10, the 2491bp SphI-SnaBI fragment of pISE17 (Gott et al. 1986; Sjöberg et al. 1986) was inserted into the $S p h I$ and $S s p I$ sites at positions 926 and 3015 of $\mathrm{pBSM}^{+}{ }^{+}$(Stratagene, Inc.). pJSS10 confers resistance to ampicillin but lacks the lac $\alpha$-complementing sequences of the vector. To construct the exon I-lacZ fusion pJZB1, pMC1403 (Casadaban et al. 1980) was cut with DraI, ligated to BamHI linkers (8-mers), cut with BamHI, and ligated to BgIII-digested pISS10. pJZE1 was made by ligating EcoRI linkers (10-mers) to DraI-digested pMCl403, cutting with EcoRI, and ligating to pJSS10 that had been linearized at the unique EcoRI site within the intron ORF (Sjöberg et al. 1986). Ampicillin-resistant transformants of lac deletion cells able to form blue colonies on X-Gal plates were selected, and their DNA subjected to restriction analysis.

The plasmids pAESI and pAH100 were used to construct the sunY exon I-lacZ and intron ORF-lacZ fusions, respectively. pAES1 contains a 1199-bp $S s p I$ fragment that includes all of exon $I$ and ends within the intron ORF, inserted into a derivative of pNC7 (Casna and Shub 1982), which has the T4 rII sequences deleted. This fragment (positions 2071-3270 of the sequence of Tomaschewski and Rüger 1987) was subcloned from pMSS48I (kindly provided by M.-Q. Xu), which contains this fragment cloned into the HincII site of $\mathrm{pBSMl}^{+}$. pAH100 contains a 785-bp HindIII fragment (positions 3179-3964 of Tomaschewski and Rüger 1987) that includes the $3^{\prime}$ end of the intron ORF and exon II sequences. The exon I-lacZ fusion, pAZHl, was constructed by ligation of HincII-digested pAES1 with pMC1871 (Shapira et al. 1983), which had been digested with Sall and filled in using Klenow fragment and dNTPs. pAZP1, the intron ORF-lacZ fusion at the PvuII site at position 3549 (Tomaschewski and Rüger 1987), was made by cutting pFR97 with HindIII, filling in the $5^{\prime}$-overhanging ends with Klenow fragment and dNTPs, digesting with DraI, and ligating to PvuII-digested pAH100.

\section{Transfer of plasmid sequences into the T4 genome}

Plasmid-containing strains at $2 \times 10^{8}$ cells $/ \mathrm{ml}$ were infected at a moi of 1 and, after $5 \mathrm{~min}$ at $30^{\circ} \mathrm{C}$, diluted 100 -fold into fresh medium. Cultures were shaken vigorously for $1-2 \mathrm{hr}$ at $30^{\circ} \mathrm{C}$ before the addition of chloroform. Progeny phage were plated and screened for recombinants using plaque hybridization techniques and/or the formation of blue plaques on X-Gal plates.

\section{Phage crosses}

To introduce a conditional defect in late transcription into the fusion phage, E. coli $\mathrm{B}_{\mathrm{E}}$ was coinfected with phage containing the intron ORF-lacZ fusions and amBL292 $\left(55_{\mathrm{am}}\right)$. Progeny phage containing both the lacZ fusions and the $55_{\mathrm{am}}$ mutation were identified as those forming blue plaques on a lawn of $l a c$ deletion cells $\left(\mathrm{Su}^{+}{ }_{\text {am }}\right)$ on X-Gal plates and by their inability to form plaques on $\mathrm{Su}^{-}$strains). Presence of the $55_{\mathrm{am}}$ mutation was confirmed by complementation spot tests. Phage containing known amber mutations and phage to be tested were spotted onto a Su- lawn at a concentration of $10^{8} \mathrm{phage} / \mathrm{ml}$, and the spots were allowed to run together. After overnight in- 
cubation at $30^{\circ} \mathrm{C}$, each combination was scored for its ability to lyse the host.

\section{$\beta$-Galactosidase assays}

$\left.\mathrm{B}_{\mathrm{E}}(\sup )^{\circ}\right)$ and $\mathrm{B}_{40}\left(\operatorname{supD}\right.$; Pribnow et al. 1981) were grown at $37^{\circ} \mathrm{C}$ in M9S medium to an $\mathrm{Abs}_{600}$ of 0.3 , infected at a moi of $\sim 7$ phage per cell, and assayed as described by Miller (1972). Cultures were sampled and assayed immediately after infection to determine background levels due to basal enzyme activity present in the cell culture and phage stock. These background levels have been subtracted from the data presented in Figure 6 .

\section{Acknowledgments}

We thank Doris Dixon for her help in constructing pDZX1 and Larry Gold for pointing out the late promoter consensus sequence preceding the $t d$ ORF. This work was supported by National Institutes of Health grants GM-33314 and GM-39422 (to M.B.) and GM-37746 (to D.A.S.), and National Science Foundation grants DMB8502961 (to M.B.) and DMB8609066 (to D.A.S.). J.M.G. and A.Z. were supported by training grants from the U.S. Army Research Office. D.A.S. was the recipient of a scholar grant from the American Cancer Society.

\section{References}

Anziano, P.Q., D.K. Hanson, H.R. Mahler, and P. Perlman. 1982. Functional domains in introns: Trans-acting and cisacting regions of intron 4 of the cob gene. Cell 30: 925-932.

Barth, K.A., D. Powell, M. Trupin, and G. Mosig. 1988. Regulation of two nested proteins from gene 49 (recombination endonuclease VII) and of a lambda Rex A-like protein of bacteriophage T4. Genetics 120 (in press).

Belfort, M., P.S. Chandry, and J. Pedersen-Lane. 1987. Genetic delineation of functional components of the group I intron in the phage T4 td gene. Cold Spring Harbor Symp. Quant. Biol. 52: 181-192.

Belfort, M., J. Pedersen-Lane, K. Ehrenman, F.K. Chu, G.F. Maley, F. Maley, D.S. McPheeters, and L. Gold. 1986. RNA splicing and in vivo expression of the intron-containing $t d$ gene of bacteriophage T4. Gene 41: 93-102.

Belfort, M., J. Pedersen-Lane, D. West, K. Ehrenman, G. Maley, F. Chu, and F. Maley. 1985. Processing of the intron-containing thymidylate synthase $(t d)$ gene of phage $\mathrm{T} 4$ is at the RNA level. Cell 41: 375-382.

Bolle, A., R.H. Epstein, W. Salser, and E.P. Geiduschek. 1968. Transcription during bacteriophage T4 development: Synthesis and relative stability of early and late RNA. $/$. Mol. Biol. 31: 325-348.

Brody, E., D. Rabussay, and D.H. Hall. 1983. Regulation of transcription of prereplicative genes. In Bacteriophage T4, (ed. C.K. Mathews, E.M. Kutter, G. Mosig, and P.B. Berget), pp. 174-183. American Society of Microbiology, Washington, D.C.

Burke, J.M. and U.L. RajBhandary. 1982. Intron within the large rRNA gene of $N$. crassa mitochondria: A long open reading frame and a consensus sequence possibly important in splicing. Cell 31: 509-520.

Carignani, G., O. Groudinsky, D. Frezza, E. Schiavon, E. Bergantino, and P.P. Slonimski. 1983. An mRNA maturase is encoded by the first intron of the mitochondrial gene for the subunit I of cytochrome oxidase in S. cerevisiae. Cell 35: $733-742$.

Casadaban, M.J., J. Chow, and S.N. Cohen. 1980. In vitro gene fusions that join an enzymatically active $\beta$-galactosidase segment to amino-terminal fragments of exogenous proteins: E. coli plasmid vectors for detection and cloning of translational initiation signals. J. Bacteriol. 143: 971-980.

Casna, N.J. and D.A. Shub. 1982. Bacteriophage T4 as a generalized DNA-cloning vehicle. Gene 18: 297-307.

Chu, F.K., G.F. Maley, F. Maley, and M. Belfort. 1984. Intervening sequence in the thymidylate synthase gene of bacteriophage T4. Proc. Natl. Acad. Sci. 81: 3049-3053.

Chu, F.K., G.F. Maley, M. Belfort, and F. Maley. 1985. In vitro expression of the intron-containing gene for $\mathrm{T} 4$ phage thymidylate synthase. I. Biol. Chem. 260: 10680-10688.

Chu, F., G.F. Maley, D.K. West, M. Belfort, and F. Maley. 1986. Characterization of the intron in the phage T4 thymidylate synthase gene and evidence for its self-excision from the primary transcript. Cell 45: 157-166.

Colleaux, L., L. d'Auriol, M. Betermier, G. Cottarel, A. Jacquier, F. Galibert, and B. Dujon. 1986. Universal code equivalent of a yeast mitochondrial intron reading frame is expressed into E. coli as a specific double strand endonuclease. Cell 44: $521-533$.

De La Salle, H., C. Jacq, and P.P. Slonimski. 1982. Critical sequences within mitochondrial introns: Pleiotropic mRNA maturase and cis-dominant signals of the box intron controlling reductase and oxidase. Cell 28: 721-732.

Depew, R.E., T.J. Snopek, and N.R. Cozzarelli. 1975. Characterization of a new class of deletions of the $\mathrm{D}$ region of the bacteriophage T4 genome. Virology 64: 144-152.

Dujon, B., L. Colleaux, A. Jacquier, F. Michel, and C. Monteilhet. 1986. Mitochondrial introns as mobile genetic elements: The role of intron-encoded proteins. In Extrachromosomal elements in lower eukaryotes (ed. R.B. Wickner, A. Hinnebusch, A.M. Lambowitz, I.C. Gunsalus, and A. Hollaender) pp. 5-27, Plenum Publishing, New York.

Ehrenman, K., J. Pedersen-Lane, D. West, R. Herman, F. Maley, and $M$. Belfort. 1986. Processing of phage T4 $t d$ RNA is analogous to the eukaryotic group I splicing pathway. Proc. Natl. Acad. Sci. 83: 5875-5879.

Gott, J.M., D.A. Shub, and M. Belfort. 1986. Multiple selfsplicing introns in bacteriophage T4: Evidence from autocatalytic GTP labeling of RNA in vitro. Cell 47: 81-87.

Gren, E.J. 1984. Recognition of messenger RNA during translational initiation in Escherichia coli. Biochimie 66: 1-29.

Guild, N., M. Gayle, R. Sweeney, T. Hollingsworth, T. Modeer, and L. Gold. 1988. Transcriptional activation of bacteriophage T4 middle promoters by the motA protein. I. Mol. Biol. 199: 241-258.

Jacquier, A. and B. Dujon. 1985. An intron-encoded protein is active in a gene conversion process that spreads an intron into a mitochondrial gene. Cell 41: 383-394.

Kassavetis, G.A. and E.P. Geiduschek. 1984. Defining a bacteriophage T4 late promoter: Bacteriophage $\mathrm{T} 4$ gene 55 protein suffices for directing late promoter recognition. Proc. Natl. Acad. Sci. 81: 5101-5105.

Kassavetis, G.A., P.G. Zentner, and E.P. Geiduschek. 1986. Transcription at bacteriophage $\mathrm{T} 4$ variant late promoters. I. Biol. Chem. 261: 14256-14265.

Lazowska, J., C. Jacq and P.P. Slonimski. 1980. Sequence of introns and flanking exons in wild-type and box3 mutants of cytochrome $b$ reveals an interlaced splicing protein coded by an intron. Cell 22: 333-348.

Lemieux, C. and R.W. Lee. 1987. Nonreciprocal recombination between alleles of the chloroplast 23S rRNA gene in interspecific Chlamydomonas crosses. Proc. Natl. Acad. Sci. 84: 4166-4170.

Macreadie, I.G., R.M. Scott, A.R. Zinn, and R.A. Butow. 1985. 
Transposition of an intron in yeast mitochondria requires a protein encoded by that intron. Cell 41: 395-402.

Macdonald, P.M., E. Kutter, and G. Mosig. 1984. Regulation of a bacteriophage T4 late gene, soc, which maps in an early region. Genetics 106: 17-27.

Mattson, T., G. van Houwe, A. Bolle, G. Selzer, and R. Epstein. 1977. Genetic identification of cloned fragments of bacteriophage T4 DNA and complementation by some clones containing early T4 genes. Mol. Gen. Genet. 154: 319-326.

McPheeters, D.S., A. Christensen, E.T. Young, and L. Gold. 1986. Translational regulation of expression of the bacteriophage T4 lysozyme gene. Nucleic Acids Res. 14: 58135826.

Michel, F. and B.F. Lang. 1985. Mitochondrial class II introns encode proteins related to the reverse transcriptases of retroviruses. Nature 316: 641-643.

Miller, J.H. 1972. Experiments in molecular genetics. Cold Spring Harbor Laboratory, Cold Spring Harbor, New York.

Mota, E.M. and R.A. Collins. 1988. Independent evolution of structural and coding regions in a Neurospora mitochondrial intron. Nature 332: 654-656.

Pedersen-Lane, J. and M. Belfort. 1987. Variable occurrence of the $n r d \mathrm{~B}$ intron in the T-even phages suggests intron mobility. Science 237: 182-184.

Pribnow, D., D.C. Sigurdson, L. Gold, B.S. Singer, C. Napoli, J. Brosius, T. Dull, and H.F. Noller. 1981. rII cistrons of bacteriophage T4. I. Mol. Biol. 149: 337-376.

Quirk, S.M., D. Bell-Pedersen, J. Tomaschewski, W. Rüger, and M. Belfort. 1988. The inconsistent distribution of introns in the T-even phages indicates recent genetic exchanges. $\mathrm{Nu}$ cleic Acids Res. (in press).

Rochaix, J.D., M. Rahire, and F. Michel. 1985. The chloroplast ribosomal intron of Chlamydomonas reinhardii codes for a polypeptide related to mitochondrial maturases. Nucleic Acids Res. 13: 975-984.

Schmelzer, C., A. Haid, G. Grosch, R.J. Schweyen, and F. Kaudewitz. 1981. Pathways of transcript splicing in yeast mitochondria. J. Biol. Chem. 256: 7610-7619.

Shapira, S.K., J. Chou, F.V. Richaud, and M.J. Casadaban. 1983. New versatile plasmid vectors for expression of hybrid proteins coded by a cloned gene fused to lacZ gene sequences encoding an enzymatically active carboxyterminal portion of $\beta$-galactosidase. Gene 25: 71-82.

Shinedling, S., D. Parma, and L. Gold. 1987. Wild-type bacteriophage $\mathrm{T} 4$ is restricted by the lambda rex genes. I. Virol. 61: $3790-3794$.

Shub, D.A. and N.J. Casna. 1985. Bacteriophage T4, a new vector for the expression of cloned genes. Gene 37: 31-36.

Shub, D.A., M.-Q. Xu, J.M. Gott, A. Zeeh, and L.D. Wilson. 1987. A family of autocatalytic group I introns in bacteriophage T4. Cold Spring Harbor Symp. Quant. Biol. 52: 193200.

Shub, D.A., J.M. Gott, M.-Q. Xu, B.F. Lang, F. Michel, J. Tomaschewski, J. Pedersen-Lane, and M. Belfort. 1988. Structural conservation among three homologous introns of bacteriophage T4 and the group I introns of eukaryotes. Proc. Natl. Acad. Sci. 85: 1151-1155.

Singer, B.S., L. Gold, S.T. Shinedling, M. Colkitt, L.R. Hunter, D. Pribnow, and M.A. Nelson. 1981. Analysis in vivo of translational mutants of the IIIB cistron of bacteriophage T4. J. Mol. Biol. 149: 405-432.

Sjöberg, B.M., S. Hahne, C.Z. Mathews, C. Mathews, K.N. Rand, and M.J. Gait. 1986. The bacteriophage T4 gene for the small subunit of ribonucleotide reductase contains an intron. EMBO J. 5: 2031-2036.

Stormo, G.D., T.D. Schneider, and L.M. Gold. 1982. Character- ization of translational initiation sites in E. coli. Nucleic Acids Res. 10: 2971-2996.

Tomaschewski, J. and W. Rüger. 1987. Nucleotide sequence and primary structures of gene products coded for by the T4 genome between map positions 48.266 and $39.166 \mathrm{~kb}$. Nucleic Acids Res. 15: 3632-3633.

Trimble, R.B., J. Galivan, and F. Maley. 1972. The temporal expression of $\mathrm{T}^{2} \mathrm{r}^{+}$bacteriophage genes in vivo and in vitro. Proc. Nat1. Acad. Sci. 69: 1659-1663.

Weiss-Brummer, B., G. Rödel, R.J. Schweyen, and F. Kaudewitz. 1982. Expression of the split gene $c o b$ in yeast: Evidence for a precursor of a 'maturase' protein translated from intron 4 and preceding exons. Cell 29: 527-536. 


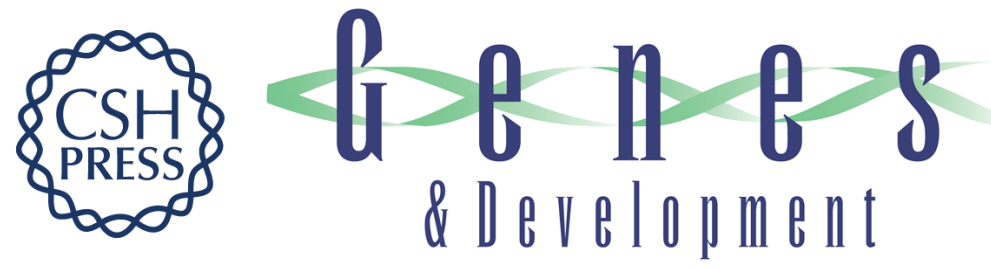

\section{Genes within genes: independent expression of phage T4 intron open reading frames and the genes in which they reside.}

J M Gott, A Zeeh, D Bell-Pedersen, et al.

Genes Dev. 1988, 2:

Access the most recent version at doi:10.1101/gad.2.12b.1791

References This article cites 45 articles, 15 of which can be accessed free at:

http://genesdev.cshlp.org/content/2/12b/1791.full.html\#ref-list-1

License

Email Alerting

Service

Receive free email alerts when new articles cite this article - sign up in the box at the top right corner of the article or click here.

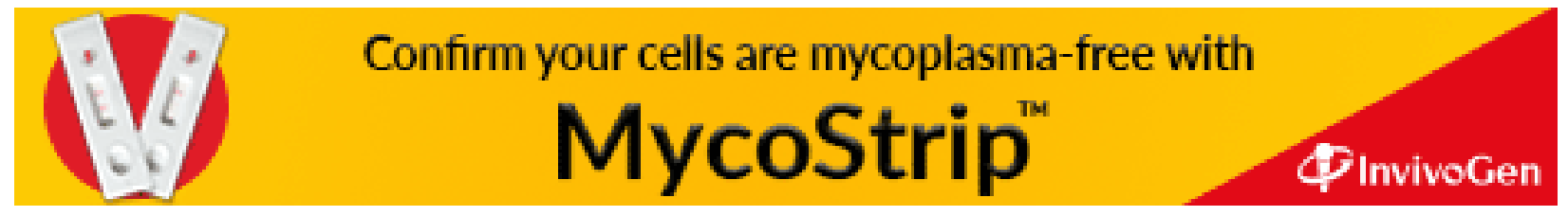

